\title{
Exterior Product Development To Improve The Entrepreneurship Of Building Engineering Vocational Schools
}

\author{
Ristiana Dyah Purwandari ${ }^{1}$, Ayu Sulasari ${ }^{2}$, Ine Kusuma Aryani ${ }^{3}$, R. Beny Wijarnako K. ${ }^{4}$ \\ $\left\{\underline{\text { ristianadyah@yahoo.com }}{ }^{1}\right.$, ayusulasaripoltek@gmail.com² $\}$ \\ Magister Pasca Sarjana Pendidikan Dasar, Universitas Muhammadiyah Purwokerto \\ ${ }_{1,3,4}$ Jl. KH. Ahmad Dahlan PO BOX 202, Kembaran, Purwokerto, Indonesia \\ Politeknik Negeri Malang \\ ${ }^{2}$ Jl. Soekarno Hatta no. 9 Kota Malang, Indonesia
}

\begin{abstract}
Entrepreneurship education in schools has only touched on the level of introduction of norms or values, and has not yet been at the level of internalization and real action in everyday life, and has not touched on the management of regional potential and entrepreneurial development in accordance with their field of expertise. The research purposes are to know the developed of the student entrepreneurial knowledge and individual attitudes through entrepreneurial learning. The research uses a quantitative approach. This carried out with the stages of pretest, treatment, posttest and questionnaire. The pretest and posttest consisted of knowledge of exterior production of wallmounted concrete and knowledge of entrepreneurship based on wall-mounted concrete products. Treatment is carried out by carrying out the practice of producing wall-mounted concrete. The measurement of the entrepreneurial spirit was carried out using a questionnaire after the treatment was carried out as the data displayed in this article. The research sample was students of SMKN 2 Purwokerto 11th grade as many as 27 students. Data processing with data recap of the questionnaire results. The percentage is done by grouping the most representative answers from the questionnaire data. In this lesson, the practice of making concrete bricks was carried out. The practice was held at the building engineering workshop of SMKN 2 Purwokerto. Students are divided into groups where each group is given the task of making one type of exterior product. This activity turned out to have an impact on increasing student achievement in entrepreneurship lessons by $9.6 \%$. While the measurement of the entrepreneurial spirit based on a questionnaire, shows the following results: 1. Student entrepreneurial knowledge, in the statement of entrepreneurial knowledge it is very necessary to equip me later in order to be successful in my business to obtain answers that strongly agree as much as $88 \%, 2$. Student's Individual Attitudes, namely in the statement of Knowledge entrepreneurship can give awareness to you to choose a profession as an entrepreneur, and $62.96 \%$ agreed answers.
\end{abstract}

Keywords: entrepreneurship learning, learning outcomes, vocational school.

\section{Introduction}

Currently, the government is promoting vocational education with the intention that the graduates will be immediately ready to work, but there are several important things that are being forgotten. Vocational School graduates are only prepared as workers, the real provision that leads 
them to become entrepreneurs has not been seen until now. So far, entrepreneurship education in schools has only touched on the level of introduction of norms or values, and has

not yet been at the level of internalization and real action in everyday life, and has not touched on the management of regional potential and entrepreneurial development in accordance with their field of expertise.

Building a mindset, attitude, providing skills and generating motivation for entrepreneurship can be done with production practices which are part of entrepreneurship training [1]. Utami and Adita stated youth has a strong character to be the main capital to become an entrepreneur in the face of the challenges of change that happened in his life, this is the reason for implementing exterior concrete production practices in Vocational Schools [2]. This research focuses on the development of exterior products carried out on the practice of making exteriors by vocational students, improving skills and knowledge through the practice of developing exterior products is expected to have an impact on the entrepreneurial spirit of vocational students.

Even though there are many things that can be developed from Vocational School graduates, one of which is the building engineering department, and later can become a business opportunity [3]. Among them is the exterior construction which was developed from lightweight concrete technology, non-sand made from the Logawa River aggregate which is abundant in Purwokerto. This business is very promising, along with the increase in housing construction and new buildings in the form of hotels, schools, amusement parks and many more, this has resulted in an increase in demand for sticky stones, even though sticking stones can be replaced by sticky concrete made from aggregate of the Logawa River[4].

Entrepreneurship learning that will be carried out in tenth grade Vocational High School is not only in the form of theory but also the practice of making products [4]. The exterior construction which was developed from lightweight concrete technology, non-sand made from the Logawa River aggregate, is one of the best products that can be created for entrepreneurship education. The materials is abundant in Banyumas Regency.

No-finesconcrete can be formed into concrete bricks which function as building walls [5]. The concrete bricks used for building walls have many advantages, including: durable, not easily weathered, is a building material that does not rust easily, can be shaped as desired, is able to withstand a high enough compressive strength, can be made by utilizing local materials which are still abundant in number such as javelin gravel and javelin gravel (javelin gravel $<0.5 \mathrm{~cm}$ in diameter while javelin gravel has a diameter between $0.5-1 \mathrm{~cm}$ ). The concrete bricks used for building walls also have other advantages, namely: no need for a plaster layer, no need for a cement surface layer and no need to be coated with paint. No-finesconcret not only can be formed into concrete bricks, it can also be formed into exterior products. Some types of exterior products are wall-stick concrete, garden table chairs or permeable paving blocks.

During its development, a lot of lightweight concrete was produced in addition to concrete bricks, it was also widely made in the form of crafts for the exterior, for example: garden pots, garden tables, chairs, even artificial ponds that can be placed in the lounge, paving blocks, sticking concrete to walls [4]. The advantages of this lightweight concrete craft are, it is durable when exposed to heat and rain, does not experience weathering or corrosion, can be placed inside or outside the room, the patterns that are displayed are very charming, there are a lot of variations in the colors and models of this craft, even the surface texture has artistic power alone. 


\section{Research Method}

The research uses a quantitative approach. The research was carried out with the stages of pretest, treatment, posttest and questionnaire. The pretest and posttest consisted of knowledge of exterior production of wall-mounted concrete and knowledge of entrepreneurship based on wallmounted concrete products. Exterior concrete is no-fines concrete with gravel material. Treatment is carried out by carrying out the practice of producing wall-mounted concrete. The measurement of the entrepreneurial spirit was carried out using a questionnaire after the treatment was carried out as the data displayed in this article. The research sample was students of (Vocational Schools) SMKN 2 Purwokerto 11th grade as many as 27 students. Data processing with data recap of the questionnaire results.

The percentage is done by grouping the most representative answers from the questionnaire data. The implementation of the treatment consists of: 1 . Students are shown the potential of the area by visiting sand mining; 2 . Students take sand samples; 3 . Students check the sand gradation of the Logawa River; 4. Logawa River sand is separated according to the size of the sand diameter; 5. Still each diameter size is grouped for exterior products; 6. Students design exterior products (adjusted for the size and coloring of non-sand concrete); 7. Students practice making exterior products (practice is done in groups). This measurement of entrepreneurial spirit is integrated into entrepreneurship subjects and local content (practice of making exteriors). This research uses the following stages: 1. Measurement of entrepreneurial spirit and student learning outcomes in entrepreneurship subjects using conventional methods (lectures), 2. Measurement of entrepreneurial spirit and student learning outcomes in entrepreneurship subjects using theoretical methods that are supported by practice (making exteriors) in accordance with the area of expertise.

\section{Results and Discussion}

3.1. Student learning outcomes and measurement of entrepreneurial spirit in entrepreneurship subjects using conventional methods (lectures).

It was found that the average value of student learning outcomes in entrepreneurship subjects using conventional methods (lectures) was 72.06. The measurement of the entrepreneurial spirit includes: Knowledge of Student Entrepreneurship and Student Individual Attitudes. To measure it using a questionnaire, the Questionnaire in Phase I and Phase II part a with questions covering Student Entrepreneurial Knowledge and Students' Individual Attitudes, the answer choices are: 1 . SA $=$ strongly agree, $2 . \mathrm{A}=$ agree, $3 . \mathrm{D}=$ disagree, and $4 . \mathrm{SD}=$ strongly disagree. Questionnaires in Phase I and Phase II part b include Students' Entrepreneurial Knowledge and Individual Attitudes of students with answers that are filled out with student opinions. The results of the questionnaire obtained the following data: 
Table 1. The results of the questionnaire in Phase I part a, followed by 27 students) SMK Negeri 2 Purwokerto

\begin{tabular}{|c|c|c|c|c|c|}
\hline \multirow[t]{2}{*}{ No. } & \multirow[t]{2}{*}{ Questionnaire Question Description } & \multicolumn{4}{|c|}{ In Percents } \\
\hline & & SA & A & D & SD \\
\hline \multicolumn{6}{|c|}{ Student entrepreneurship knowledge } \\
\hline 1. & $\begin{array}{l}\text { Entrepreneurial knowledge is very necessary } \\
\text { to equip me later to be successful in business. }\end{array}$ & 88.89 & 11.11 & & \\
\hline 2. & $\begin{array}{l}\text { Entrepreneurial knowledge can increase the } \\
\text { success of my business in the future }\end{array}$ & 55.55 & 44.44 & & \\
\hline \multicolumn{6}{|c|}{ Individual Attitudes of students } \\
\hline 3. & $\begin{array}{l}\text { Entrepreneurial knowledge can provide } \\
\text { enthusiasm and encouragement for you to be } \\
\text { entrepreneurial }\end{array}$ & 59.25 & 33.33 & 7.41 & \\
\hline 4. & $\begin{array}{l}\text { Entrepreneurial knowledge is not very } \\
\text { important, because I want to be an employee, } \\
\text { not an entrepreneur. }\end{array}$ & 3.7 & 3.7 & 44.44 & 48.14 \\
\hline 5. & $\begin{array}{l}\text { Entrepreneurial knowledge is only knowledge } \\
\text { provided in entrepreneurship subjects and is } \\
\text { compulsory for all students to be able to } \\
\text { graduate from school. }\end{array}$ & 3.7 & 11.11 & 48.14 & 37.03 \\
\hline
\end{tabular}

Table 2. Questionnaire results in Phase I part b, followed by 27 students) SMK Negeri 2 Purwokerto

\begin{tabular}{|c|c|c|c|}
\hline No. & Questions & \multicolumn{2}{|c|}{$\begin{array}{l}\text { Questionnaire } \\
\text { Results }(\%)\end{array}$} \\
\hline \multicolumn{4}{|c|}{ Entrepreneurial Knowledge } \\
\hline \multirow[t]{8}{*}{1.} & Has the Entrepreneurship Knowledge that you acquired since the first & & \\
\hline & $\begin{array}{l}\text { semester of class } X \text {, can give you a picture of real business activities or the } \\
\text { real world for you? }\end{array}$ & $\begin{array}{l}\text { Not yet } \\
44\end{array}$ & $\begin{array}{l}\text { Done } \\
56\end{array}$ \\
\hline & $\begin{array}{l}\text { If so, state what business descriptions are in your mind right now, give } \\
\text { descriptions and examples. } \\
\text { - Trade }\end{array}$ & \multicolumn{2}{|c|}{44} \\
\hline & - Selling services & \multicolumn{2}{|c|}{4} \\
\hline & - Contractor & \multicolumn{2}{|c|}{8} \\
\hline & - Chicken livestock & \\
\hline & - Producing goods & \multirow{2}{*}{\multicolumn{2}{|c|}{40}} \\
\hline & $\begin{array}{l}\text { - Doubtful about entrepreneurship, it would be better if } \\
\text { Entrepreneurship is supported by practice }\end{array}$ & & \\
\hline
\end{tabular}




\begin{tabular}{|c|c|c|c|}
\hline 2. & Individual Attitudes of Students & & \\
\hline & $\begin{array}{l}\text { In your own opinion, what things and abilities should an } \\
\text { entrepreneur have? Do you already have this ability? If not, what } \\
\text { would you like to do? }\end{array}$ & & \\
\hline & $\begin{array}{l}\text { I feel I already have the skills that must be owned in } \\
\text { entrepreneurship }\end{array}$ & \multicolumn{2}{|c|}{ - } \\
\hline & $\begin{array}{l}\text { I feel that I don't have the skills that must be possessed in } \\
\text { entrepreneurship }\end{array}$ & \multicolumn{2}{|c|}{64} \\
\hline & $\begin{array}{l}\text { I feel that I don't have the skills that must be possessed in } \\
\text { entrepreneurship so I want to continue learning }\end{array}$ & \multicolumn{2}{|c|}{36} \\
\hline & $\begin{array}{l}\text { Do you think that the entrepreneurial knowledge that has been } \\
\text { provided so far is only in the form of theory so that it is boring and } \\
\text { has no impact on what you think and what you want to do? }\end{array}$ & $\begin{array}{l}\text { No } \\
36\end{array}$ & $\begin{array}{l}\text { Yes } \\
64\end{array}$ \\
\hline & Why so? & & \\
\hline & $\begin{array}{l}\text { It should not only be in theory but with practice, for example } \\
\text { managing a small business }\end{array}$ & \multicolumn{2}{|c|}{79.16} \\
\hline & Entrepreneurial theory has spurred me to become entrepreneurial & \multicolumn{2}{|c|}{20.83} \\
\hline
\end{tabular}

2. Student learning outcomes and measurement of entrepreneurial spirit and in the entrepreneurship subject use theoretical methods supported by exterior production practices. It was found that the average value of student learning outcomes in the entrepreneurship subject using theoretical methods supported by entrepreneurial practice according to the area of expertise in the next semester (even) was 79, this means that there was an increase of 9.6\%. The measurement of the entrepreneurial spirit is carried out after the practical activity of making exterior products, as shown in the image below:
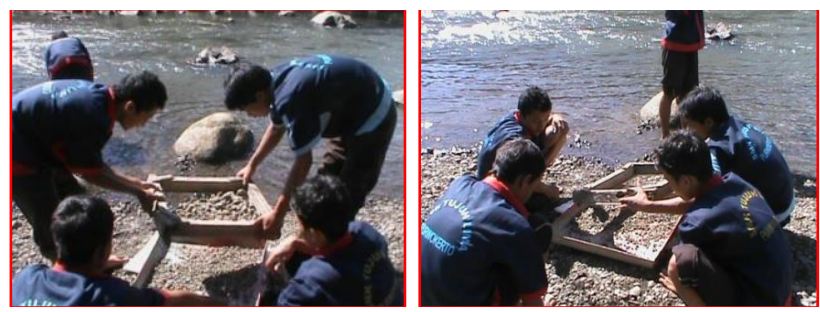

Picture 1. Vocational school student activities observing Krisik gravel material along

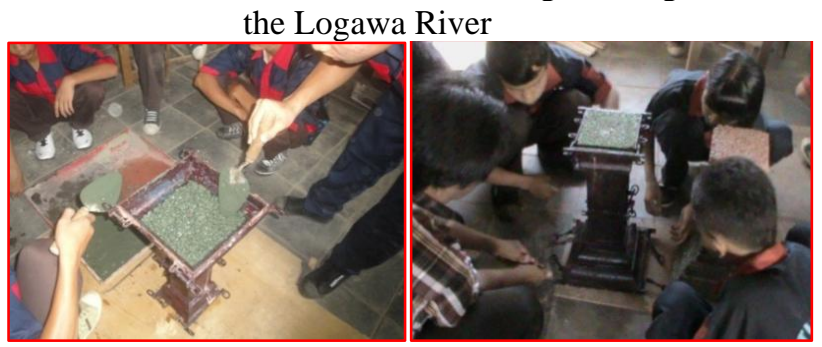

Picture 2. Garden table production practice activities 


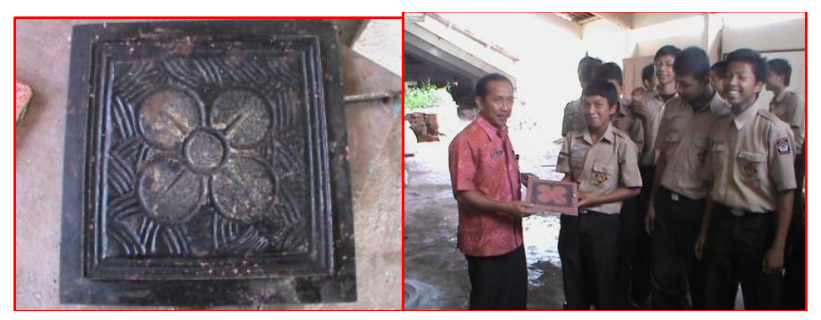

Picture 3. Practical activities to make various kinds of exterior products

The results of the second stage of the questionnaire after the practice of exterior concrete products are in Table 3 and Table 4.

Table 3. Questionnaire results in Phase II part a, followed by 27 students)

SMK Negeri 2 Purwokerto

\begin{tabular}{|c|c|c|c|c|c|}
\hline \multirow[t]{2}{*}{ No. } & \multirow[t]{2}{*}{ Questionnaire Question Description } & \multicolumn{4}{|c|}{ In Percents } \\
\hline & & SA & A & D & SD \\
\hline \multicolumn{6}{|c|}{ Student entrepreneurship knowledge } \\
\hline 1. & $\begin{array}{l}\text { Entrepreneurial knowledge is very necessary to } \\
\text { equip me later to be successful in business. }\end{array}$ & 79.31 & 17.24 & 0 & 3.44 \\
\hline 2. & $\begin{array}{l}\text { Entrepreneurial knowledge can increase the success } \\
\text { of my business in the future }\end{array}$ & 48.27 & 48.27 & & 3.44 \\
\hline \multicolumn{6}{|c|}{ Individual Attitudes of students } \\
\hline 3. & $\begin{array}{l}\text { Entrepreneurial knowledge can provide enthusiasm } \\
\text { and encouragement for you to be entrepreneurial }\end{array}$ & 27.58 & 65.51 & 3.44 & 3.44 \\
\hline 4. & $\begin{array}{l}\text { Entrepreneurial knowledge is not very important, } \\
\text { because I want to be an employee, not an } \\
\text { entrepreneur. }\end{array}$ & 17.24 & 10.34 & 48.27 & 24.13 \\
\hline 5. & $\begin{array}{l}\text { Entrepreneurial knowledge is only knowledge } \\
\text { provided in entrepreneurship subjects and is } \\
\text { compulsory for all students to be able to graduate } \\
\text { from school. }\end{array}$ & 3.57 & 28.57 & 35.71 & 32.14 \\
\hline
\end{tabular}


Table 4. Questionnaire results in Phase II part b, followed by 27 students)

SMK Negeri 2 Purwokerto

\begin{tabular}{|c|c|c|c|}
\hline No. & Questions & \multicolumn{2}{|c|}{$\begin{array}{l}\text { Questionnaire } \\
\text { Results (\%) }\end{array}$} \\
\hline \multicolumn{4}{|c|}{ Entrepreneurial Knowledge } \\
\hline \multirow[t]{8}{*}{1.} & \multirow{2}{*}{$\begin{array}{l}\text { Has the Entrepreneurship Knowledge that you acquired since the first } \\
\text { semester of class X, can give you a picture of real business activities or the } \\
\text { real world for you? }\end{array}$} & \multicolumn{2}{|c|}{ Answer } \\
\hline & & $\begin{array}{l}\text { Not yet } \\
34.48\end{array}$ & $\begin{array}{l}\text { Done } \\
65.51\end{array}$ \\
\hline & $\begin{array}{l}\text { If so, state what business descriptions are in your mind right now, give } \\
\text { descriptions and examples. } \\
\text { - Trade }\end{array}$ & \multicolumn{2}{|c|}{24.13} \\
\hline & - Selling services & \multicolumn{2}{|c|}{13.79} \\
\hline & - Contractor & \multicolumn{2}{|c|}{20.68} \\
\hline & - Chicken livestock & \multicolumn{2}{|c|}{6.89} \\
\hline & - Producing goods & \multicolumn{2}{|c|}{6.89} \\
\hline & $\begin{array}{l}\text { - Doubtful about entrepreneurship, it would be better if } \\
\text { Entrepreneurship is supported by practice }\end{array}$ & \multicolumn{2}{|c|}{27.58} \\
\hline \multirow[t]{9}{*}{2.} & Individual Attitudes of Students & & \\
\hline & $\begin{array}{l}\text { In your own opinion, what things and abilities should an } \\
\text { entrepreneur have? Do you already have this ability? If not, what } \\
\text { would you like to do? }\end{array}$ & & \\
\hline & $\begin{array}{l}\text { I feel I already have the skills that must be owned in } \\
\text { entrepreneurship }\end{array}$ & \multicolumn{2}{|c|}{3.44} \\
\hline & $\begin{array}{l}\text { I feel that I don't have the skills that must be possessed in } \\
\text { entrepreneurship }\end{array}$ & \multicolumn{2}{|c|}{17.24} \\
\hline & $\begin{array}{l}\text { I feel that I don't have the skills that must be possessed in } \\
\text { entrepreneurship so I want to continue learning }\end{array}$ & \multicolumn{2}{|c|}{75.86} \\
\hline & $\begin{array}{l}\text { Do you think that the entrepreneurial knowledge that has been } \\
\text { provided so far is only in the form of theory so that it is boring and } \\
\text { has no impact on what you think and what you want to do? }\end{array}$ & $\begin{array}{l}\text { No } \\
25\end{array}$ & $\begin{array}{l}\text { Yes } \\
75\end{array}$ \\
\hline & Why so? & & \\
\hline & $\begin{array}{l}\text { It should not only be in theory but with practice, for example } \\
\text { managing a small business }\end{array}$ & \multicolumn{2}{|c|}{74.1} \\
\hline & $\begin{array}{l}\text { - Entrepreneurial theory has spurred me to become } \\
\text { entrepreneurial }\end{array}$ & \multicolumn{2}{|c|}{25.9} \\
\hline
\end{tabular}

Based on questionnaire data at stage I and stage II, it is found that:

a. Student Entrepreneurship Knowledge

Knowledge of entrepreneurship can provide me with preparation to start a business, students say $10.34 \%$ Disagree compared to stage I. The two things above are because many students want the knowledge of entrepreneurship not only to cover theory but more thoroughly such as direct 
practice to produce (exterior) with creativity that they can develop themselves and want to be directly involved in managing a business even though the scope is small under school guidance.

This can be explained that adult students equivalent to vocational students basically already have an entrepreneurial mentality, this needs to be strengthened in entrepreneurial practice. One of the characteristics of entrepreneurship is a strong mentality [6]. According to the researcher, one of the ways to build a strong mentality is by providing skills that become self-confidence motivation that has the ability and skills in production. This is supported by the data in questionnaire $b$, namely in the statement: hesitating to become entrepreneurial, it would be better if entrepreneurship is supported by practice, there is an increase in the percentage of $7.58 \%$ from stage I. and supported in section c, the statement of being hesitant about entrepreneurship which in stage I reaches $20 \%$, then after the activities supporting the practice of producing exteriors, in stage II the percentage is $0 \%$, it appears that there is a desire from students or an inspiration for entrepreneurship.

\section{b.Students' Individual Attitudes}

Based on the questionnaire data for part a in stage I and stage II, there is an increase in the number of percentages in the choice strongly agree and agree on items follow: (1) Knowledge of entrepreneurship can provide enthusiasm and encouragement for you to be entrepreneurial; (2) Entrepreneurial knowledge can give you awareness to choose a profession as an entrepreneur; (3) Entrepreneurs who are good and qualified must have the ability to solve problems; and (4) Good and quality entrepreneurs must have knowledge from various fields of science. Then, there is an increase in the number of percentages in the statement disagree and strongly disagrees on item Entrepreneurs with quality only need persistence.

Based on Table 2-4, it shows that the individual attitudes of students tend to have a greater desire for entrepreneurship when compared to measuring the attitudes of stage I towards stage II. This shows that in principle entrepreneurship will build knowledge and skills and requires vocational students to be involved in practice [7]. According to researchers, the practice of exterior products can increase students' knowledge and also strengthen their entrepreneurial spirit. Entrepreneurship training through exterior products is one way to develop motivation and interest and generate new ideas from youth to enter the world of entrepreneurship [8]. Improving the thinking skills and skills of Vocational School students to become more productive can be done by attend entrepreneurship training [9].

\section{Conclusions}

Student Entrepreneurship Knowledge tend increased after they practice of exterior concrete products. This tend also to individual attitudes of students. The tendency of these two things should be followed up with practice-based entrepreneurship education that supports their future.

\section{References}

[1] Hasdar M, Bashar A, Wadli W. Penumbuhan Jiwa Wirausaha Siswa SMK Ma'arif NU 01 Wanasari Melalui Pelatihan Pengolahan Limbah Air Kelapa. JPM PAMBUDI. 2019 Aug 31;3(1):29-37.

[2] Utami SN, Adita MD. Pengenalan Analisis Break Even Point (BEP) Sebagai Bekal bagi Mahasiswa Ilmu dan Teknologi Pangan Dalam Menumbuhkan Jiwa wirausaha. Randang 
Tana-Jurnal Pengabdian Masyarakat. 2019 Jan 21;2(1):54-60. [3] Ni H, Ye Y. Entrepreneurship education matters: exploring secondary vocational school students' entrepreneurial intention in China. The Asia-Pacific Education Researcher. 2018 Oct;27(5):409-18.

[4] Purwandari RD. Pengembangan Teknologi No-Fines Concrete dengan Memanfaatkan Agregat Sungai Logawa sebagai Produk Eksterior untuk Meningkatkan Jiwa Wirausaha Siswa SMK”, Prosiding Seminar Nasional Fisika 2012, ISBN 978-602-97835-2-0, UNESS.

[5] Tjokrodimuljo, K. Teknologi Beton, Buku Ajar, Jurusan Teknik Sipil, Fakultas teknik, UGM, Yogyakarta. 1996,

[6] Maulida AN, Kusumah IH, Permana T. Karakteristik Sikap Mental Wirausaha Mahasiswa Dalam Bidang Otomotif. Journal of Mechanical Engineering Education. 2016 Jun;3(1):9-15

[7] Christanti A. Studi Peranan Pelatihan Kewirausahaan Terhadap Pembentukan Sikap Dan Intensi Kewirausahaan Di Sentra Industri Produk Roti Dan Kue Rungkut Lor, Surabaya. Agora. 2016 Mar 2;4(1):242-8.

[8] Firdaus V, Hasanah H. Pengaruh Pelatihan Dan Pendidikan Kewirausahaan Terhadap Motivasi Berwirausaha Pada Penyandang Disabilitas di Kabupaten Jember. Fenomena. 2018 Oct $31 ; 17(2)$.

[9] Gayatri AM, Rahayu EI. Pemberdayaan Siswa SMK melalui Pelatihan Keterampilan dengan Pemanfaatan Kain Perca sebagai Peluang Usaha. Sosio e-Kons. 2015 Dec 16;7(3). [17] Utami, S.N dan Adita, M.D. 2019. Pengenalan Analisis Break Even Point (BEP) Sebagai Bekal Bagi Mahasiswa Ilmu dan Teknologi Pangan Dalam Menumbuhkan Jiwa Wirausaha. Randang Tana: Jurnal Pengabdian Masyarakat. 2 (1) : 54- 60. 